\title{
"Debajo de la mierda": The Subversive Dialogue Between Nicanor Parra and David Aniñir
}

\author{
Sandra Collins \\ (University of Aberdeen)
}

[Accepted for publication: 15 May 2018]

\begin{abstract}
$\mathrm{T}^{\mathrm{n}}$ a symposium on the legacy of Nicanor Parra in the University of Chile, Walter 1 Höefler equated antipoetry to the "problema mapuche", because "se adquieren tierras que ya pertenecen a alguien, pero no lo sabemos, o peor, no queremos saberlo" (in Quezada et al. 2015, 158). He went on to elaborate:

El sujeto de la poesía de Parra habla siempre desde el lenguaje, está siempre de paso, en fuga o en retornos breves a un ilusorio lugar de origen. Es curioso, no crea ni revive espacios íntimos. Solo en la vida real el poeta posee algunas casas, pero también las abandona.
\end{abstract}

Höefler's metaphor is intriguing; as one occupies another's territory, the remnants of their language, customs and "un cierto saber ancestral" (158), combined with common speech and assumptions, can only ever amount to fragmentary, inconclusive discourse. The act of intrusion cannot be concealed by language, as so much of speech derives from the place that has been occupied. In the case of Chile, the stolen space of La Araucanía has been mythified in poetry, and the original occupiers subsequently celebrated as ghosts, willing martyrs to a shared vision. ${ }^{1}$ Antipoetry, the movement that rebelled against sentimental idealism, exposes the duplicity of such poetic devices. In abandoning both claims to a fixed origin and a desire to speak for others, it is condemned to a self-mocking, uneasy existence.

Reference to the Mapuche problem on Höefler's part is multi-layered; as well as calling to mind issues around linguistic hybridity in Chile, he also invokes a fundamental dilemma at the heart of Chilean identity: the denial of the indigenous element of society, which can be traced back to the attempted genocide of the Mapuche people and subsequent usurpation of their territory carried out by the

\footnotetext{
1 Among the most persistent of these expressions is the noble savage trope found in Pablo Neruda's Canto general (1950), which views the sixteenth-century Mapuche warrior as freedom fighter and forefather to the predominantly mestizo contemporary Chileans.
}

Journal of Antipoetry Studies - Revista de Estudios Antipoéticos 1 (2018): 1-18.

ISSN: 2399-2069 - Article DOI: https://doi.org/10.18573/japs-revesa.6

This work is licensed under a Creative Commons Attribution 4.0 International Licence.

URL: https://creativecommons.org/licenses/by/4.0/

The copyright of this article is owned by the author. 
Chilean State in the late nineteenth and early twentieth centuries. The abandoned houses, unlike many disputed territories elsewhere in Latin America, were occupied in the not-too-distant past. ${ }^{2}$ When describing antipoetry as commensurate with the great Chilean paradox (the simultaneous glorification and rejection of indigeneity), Höefler also demonstrates his awareness of Parra's position with respect to the Mapuche people. As tensions mounted between Mapuche communities and the democratic Concertación and Nueva Mayoría governments (1988-2013 and 20132018, respectively), Parra became increasingly involved in Mapuche affairs. In 2010, at the age of ninety-six, he went on hunger strike in solidarity with the fifty-two Mapuche prisoners on trial under the notorious anti-terrorist law (Gómez-Barris 2012; Haughney 2012). The impact of Parra's literary engagement with Mapuche cultural production is also significant; he was one of the non-Mapuche poets who participated in a Zugutrawun ("Reunión de la palabra") in 1994, an event set up to exchange perspectives on the emerging Mapuche canon (Mora Curriao 2007, 36).

The influence of Parra and antipoetry are frequently pointed out in the work of the urban-based poet David Aniñir Guilitraro, although critics never go beyond a mere mention of it; there is much scope as to the significance of contemporary antipoetry among the Mapuche youth of Chile and Argentina. Aniñir is seen as the forerunner of the sociocultural movement now known as Mapurbe after his poetry collection of the same title, originally published in 2005. While the elements of antipoetry are immediately evident in the free form, playfulness and language he employs-using symbols instead of words, for example (Preston 2017, 74)—, the motivation behind the use of such techniques has taken on a renewed vigor in the form of the hybrid Mapurbe aesthetic (Kropff 2004 and 2011; Osorio Santibáñez 2009; Cárcamo-Huechante 2010; Collins 2014). As a first generation Huilliche (southern) Mapuche in Santiago, Aniñir's urban condition is the outcome of the forced migration and pauperization that followed the occupation of Mapuche communities (lofs) on Mapuche territory (Aravena 2002). Aniñir is a builder by trade and has struggled to produce poetry at night; he is Parra's "albañil que construye su muro" ([1969] 1983, 154) made incarnate, reconstructing the language and reality of his life in the ghettos of Santiago. The theme of social injustice is evident in the poem "Mapurbe" when he describes the condition of the Mapuche of the urbe as a curse: "Nacimos en la mierdópolis por culpa del buitre cantor / Nacimos en panaderías para que nos coma la maldición" $(2009,75)$. The creation of Aniñir's mierdópolis, as a microcosm of Chilean injustice, is a "venganza a raíz" following the uprooting of his

\footnotetext{
2 Neither chronological accuracy nor the ongoing human rights abuses committed against the Mapuche are considered when referring to the so-called terrorist threat of La Araucanía (Mapuche territory), where clashes between police and Mapuche communities looking to restore their ancestral lands occur on a daily basis. Many Chileans hold anachronistic ideas of nationhood, assuming for example that the Spanish were responsible for all atrocities committed against the Mapuche, rather than recognizing that the usurpation occurred when Chile was already long established as an independent nation.
} 
family from their territory in the south of Chile. Revenge is viewed as regenerative, having led to new art forms that have had a tangible impact on the lives of young Mapuche people, and subsequently on their engagement with the ongoing political and ecological struggle. In an interview, Aniñir (201lb) cites Parra and antipoetry as major influences, "no tanto en lo lírico sino en su actitud de ver el mundo, saber que debajo de la mierda hay algo de belleza, buscar la belleza en espacios así".

Parra has been increasingly lauded for contributing to the awakening of an ecological vision in keeping with Mapuche spiritual beliefs (Samaniego Mesías and Ruiz Rodríguez 2007, 114). As Aniñir demonstrates, the indigenous condition and connection to ancestral territory varies and mutates, thus requiring different decolonizing strategies. As the full title of his collection suggests (Mapurbe: venganza a raíz), Parra's repeated call to "cambiarlo todo de raíz" is restated as a dominant theme; this involves reassessing the capitalist, consumerist trajectory that has set Chile, and much of the globe, on a path to destruction. Aniñir's "venganza a raíz" requires a revenge on everything; language, poetry and even his own ancestral traditions become objects of his derision. Although Aniñir recognizes that the Mapuche struggle is one among many across the world (Santillán 2014), he has expressed discomfort with his categorization in the literary world as a Mapuche poet, as though his Mapuche condition were a novelty factor that allowed him to bypass aesthetic judgement. He is primarily a poet, and one who writes about his own reality: "Lo mapuche es mi condición pero no por mi condición soy poeta" (Aniñir 201lb). At the same time, the tension between the desire to reflect his reality while simultaneously honouring the spiritual laws of his ancestors does not inevitably lead to cultural destruction but rather enriches the world he creates; the two compulsions are not mutually exclusive. While Parra and Aniñir emerge from diverse backgrounds in Chile and subsequently draw from opposing knowledge systems that critique the literary establishment from different angles, both acknowledge beauty "debajo de la mierda". Both poets explore the absurdities, ironies, humour and ridiculousness of language and society but also search for an alternative view of the world that could lead to ecological preservation. This article explores the discursive dialogue that unfolds between the two poets when read with this mutual quest in mind.

\section{Repartir mierda con ventilador... para todos lados}

$A$ niñir joined a number of poets in an online article to pay respects to the recently A deceased Parra: "Pusiste a la muerte en cuatro patas y luego te viraste pa'l Olimpo, pewka yeal don Nica" ("Nicanor Parra” 2018). The irony in Aniñir's referral to Parra's retreat to Olympus is not lost on the reader. Aniñir himself has urged

3 In MapUrbe'zine ("Conversa con el David" 2004), Aniñir also identifies Parra as influential in his literary creation, particularly for his use of play on words and neologisms. 
poets to come down from Olympus on numerous occasions; the line from Parra's "Manifiesto" is often quoted in interviews. And yet, his reference to the poet as "don Nica" is both deferential and irreverent, and his farewell salutation "pewkayeal" (meaning "we shall see each other again") calls upon a tradition where there is continuity between the world of the living and the dead. Aniñir's salutation defies the gravitas associated with death and literary greatness; the fusion of Mapuche and Western/European heritage demonstrates that humour often results from linguistic and cultural interchange. The exploration of different aspects of his identity allows Aniñir this same deftness in his poetry, as it can be read on a number of semiotic and linguistic levels. At the same time, the anguish that results from writing from the margins is a theme in much of his work.

As Joanna Crow (2008) points out, Aniñir parallels Charles Hale's "antagonistic indian" in his refusal to dialogue or conform to the expectations of state institutions. Aniñir's marginal position has been analyzed in relation to his urban indigenous identity, the complications that have arisen in relation to his economic condition, his spiritual heritage, which is related to language (Collins 2014) and more recently, his masculinity (Garside 2016). These factors set apart Aniñir's exploration of the complexities, themes and nuances of the growing Mapuche literary tradition from many of his contemporaries. His response to the literary establishment as primarily rebellious (Crow 2015,5) stands out from many of the more celebrated Mapuche poets, many of whom are (unwillingly) co-opted by the Chilean State in order to demonstrate a commitment to multiculturalism. Aniñir is alienated both from the Chilean academy and his native culture, the rich heritage of oral traditions of $\ddot{u}$, nutram, etc. as well as Mapudungun rhetoric, which are often seen as 'living poetry' and in danger of disappearing as a direct result of Eurocentric policies. As many literary scholars have noted, spiritual concepts are carried over into written Mapuche poetry even in cases when the language has been lost; urban poetry is no exception (Geeregat and Gutiérrez 1992; Merino 1999; Barrera García 2008). His refusal to buy into any fundamentalist discourse with regard to either Chilean/Western or Mapuche culture is reinforced in his work through antipoetic strategies which will be discussed in the following section. However, Aniñir's "literary acts of decolonisation", which force dialogue even as he appears to eschew it (Crow 2015), are also carried out in the spirit of Parra, who ultimately aspired to push figures of the literary establishment, as well as the reader, out of their complacency. This intention famously expressed by Parra to "repartir mierda con ventilador...para todos lados" (quoted in Yamal 1986, 277) also permeates much of Aniñir's work.

In his poem "Autoretraxto", Aniñir (201la) exposes his relationship to poetry as simultaneously oppressive and liberating. An answer to the self-portraits of Neruda and Parra, Aniñir's poem exposes the pain that poetry has caused him, not only because of his dire economic situation, but also because of the shame his words provoke among the older more traditional members of his community: 
Apaga la luz que sale cara

Como tú no la pagaí

Se ve mal pa' tu cultura

Tu actitud David

Siempre en excesos

Por más que le pongai newendy

No te da vergüenza

Eres peor que la nada

Tan autodestructivo que me saliste

Hasta cuando David

Los poetas desconfían de ti

Te ven muy flayte

En la Sociedad de Escritores de Chismes.

While the jaded teacher in Parra's "Autorretrato" $(1954,53)$ has lost his voice "haciendo clases" (72) during his "quinientas horas semanales" (73), a mother's voice emerges as the most dominant in Aniñir's self-portrait. It is an assailment on the poet's failures: his obsession with poetry that gains him disapproval from his literary peers, a tendency towards excess which is deemed 'un-Mapuche', his inability to work enough to cover the electricity bills racked up writing at night. Despite contrasting tone and voice, an identity crisis is acute in both characters, manifesting in the physical appearance of decay in Parra's teacher ("esta nariz podrida" [55], "estas mejillas blancas de cadáver" [56]) and in Aniñir's spiritual loss that results from a betrayal of indigenous culture. ${ }^{4}$ The teacher in Parra's poem is rendered stagnant, "embrutecido" $(1954,56)$ by the malaise characteristic of Western/European literature; his existential crisis is such that he is unable to recognize his own mother (55). Conversely, it is the voice of Aniñir's mother and the acute awareness of origin that causes his own crisis; its spiritual nature is revealed in the second half of the poem:

Déjate de poesías, plagiador

Todos saben que tus poewmas

Son del imaginario mapuche

Que se te devienen en sueños

Por lo menos explica al lector, al pie de página

Que violaste los derechos de autor de tus antepasados

\footnotetext{
4 The voice alludes to a process of what, in the Mapuche context, is known as awinkamiento, becoming like the winka (non Mapuche) which has often been used to warn Mapuche people against loss of their culture. Here the voice accuses Aniñir of betraying his ancestors, even though they have sought him out through pewma ("dreams"-Aniñir's neologism poewmas denotes a foulness and lack of purity in his own) from the spirit plane of Wenu Mapu. Thus, Aniñir's violation against the rights of his ancestors can be seen on a number of levels. The first that springs to mind is the violation of spiritual laws known as az mapu that connect Mapuche people to the Earth, and which require rituals and decorum that are arguably impossible to carry out in an urban setting.
} 
Y por favor déjate de andar ponceando en Facebook

Andaí puro feibuceandoooooo

Trabaja, trabaja mejor y déjate de poesías

Que de poemas nadie come. (Aniñir 201la)

While Aniñir is a part-time, self-educated poet, Parra appears as an overworked secondary school teacher, who has exhausted himself regurgitating theory that will ultimately destroy his own students in the same way he has been destroyed. Aniñir will never earn his bread from poetry, yet Parra's teacher despises himself working as a lackey for a class that is responsible for nameless atrocities. The bread he earns is therefore "imperdonable / duro como la cara del burgués / y con sabor y con olor a sangre" (Parra [1969] 1983, 54).

In both poems, pathos is kept in check by an urge to communicate at the most intimate, and therefore ribald, level. Aniñir's urban condition is exacerbated by the flayte (chav) persona he embraces, a social identity related to the delinquent often used by the Chilean media to sensationalize the threat that lower class criminals pose to society. Such associations cause further disapproval among the literary community, who find the lack of education, vulgar speech and menacing attitude unpalatable. Aniñir resorts to spreading his ideas through social media, "puro feibuceandoooooo", producing on a collective platform that is arguably more spontaneous and reaches more young people in the long run. Language is alive, has relevance and when organized can have a real impact on the political situation of Chile. Aniñir thus reaches a wider net of young people who might otherwise be alienated from less accessible poetry that is confined to academic circles. His actions arguably venerate his ancestors, but not in the way they would necessarily have valued. The nagging voice of the mother becomes drowned out as the compulsion to write and share on a younger platform takes over. In a similar vein, the portrait of despair in Parra's caricature performs a stimulating function against the stagnation of the classroom. The poem is in itself a commentary on the seriousness of the academy precisely because it abandons the heavy imagery of tradition and focuses instead on irony, humour and hyperbole. Out of intellectual rot and loss comes recreation.

Exasperation with the literary world reveals a deeply rooted spiritual crisis, which manifests in weariness and guilt; both poets transform their personal anguish into an object of ridicule. At the same time, the modification of the poetic form demonstrates their desire to reveal the underlying seriousness of such crises. Parra's personification of poetry, whose virtuousness and decorum bores the poet until poetry is forced to leave (see "La poesía terminó conmigo" [(1969) 1983, 80]: "la poesía se ha portado bien / yo me he portado horriblemente mal / la poesía terminó conmigo") leads to the creation of antipoetry in an attempt to do away with obligation, to find an honest relationship with a form that is not weighed down by literary conven- 
tion. Frustration is palpable throughout Mapurbe when Aniñir cannot understand his ancestral tongue: "la poesía que viene hacía mí / balbuceando bellos sarcasmos / de mapuche muertos que quieren reír / y llorar por mí en el verso" (2009, 31). In another poem, Poetry arrives as a whore against whom the poet is warned for her promiscuity and blasphemous way of speaking until he finally succumbs (71). Thus his resulting poetic creation, his mapuchemes, are depicted as broken and foul: "elásticos quemados / Cenizas / Rimas de vientos ancestrales" (25), "peótikas narraciones en las calles malolientes" (45).

The same treatment is given to language; while the imagery and conversational tone often result in hilarity, the intent behind the use of colloquial chilenismos and the inventiveness behind the creation of neologisms is political in nature. Likewise is its diffusion; publishing poetry on a blog, through YouTube and through spontaneous meetings and spoken-word events, Aniñir, like Parra, demonstrates that art should not be exalted, but rather belongs in everyday speech and public spaces. We have seen how the comic exposure of the anti-hero communicates the poets' solitude with the wider community. In the following section I will show how the desacralization of language and societal institutions are a further step towards an art form that is more inclusive.

\section{Language, Desacralization and the Corporeal}

The imprint of Parra on Aniñir's work is evident in the layout of his poems: the use of capitals, brevity, parentheses, and humorous neologisms all serve Aniñir's purpose to reflect the often bleak reality of the periphery of Santiago. The organic formation of his poetry, "mi formación con mis pares, el habla, la conversa, lo experiencial", reflects the speech of the pobla (poblaciones), the neighbourhoods on the periphery of Chile's capital (Aniñir 2011b). A distinguishable feature of his written work is the use of the grapheme $\langle k\rangle$, which has become part of the quintessential Mapurbe aesthetic, at once a rejection of the norms of the Spanish language and reminiscent of global youth and text speak. Another aspect, and one which continues to influence young Mapuche musicians, is the preservation of the spontaneity and orality of the Mapudungun language; the incorporation of traditional elements of $\ddot{l} l$ (Mapuche song) lends itself to public performance and theatre. Even though Aniñir did not grow up speaking Mapudungun, he is familiar with words and concepts and has worked with native speakers to translate some of his poetry. $\mathrm{He}$ also celebrates the vitality of the hybrid vernacular. His ironic glossary (2009, 9396) mixes vulgarisms used by construction workers, national slang, and words and concepts from Mapudungun. Therefore, while most Chileans reading his glossary would understand some of the sexual jokes_-paja (93), mula (94) etc.-, they may not understand the Mapuche words. His use of bilanguaging, or non-translation of a hybrid language (Mignolo 2000, 264; Collins 2014, 9), is an attack against the 
forces that led to the loss of his own native tongue, and arises from the necessity to create a system of communication that better reflects the Mapurbe neocolonial situation. Just as the Earth (Mapu) and language (Mapudungun, "language of the Earth") are inherently connected, Mapuche physical continuity and poetry also go hand in hand: "Poetry allows the individual to connect with the world in its purest form and subsequently frees the body from systemic oppression; it is the languaging of decolonization" (Collins 2014, 35).

Chilean literature has been recognized as a realm wherein the indigenous subject has been desexualized according to the political or aesthetic needs of the ruling class. The reversal of the asexual noble savage to the taking on of the flesh-and-blood angry Indian serves as a reminder that indigenous resistance remains a tangible conflict in a country that prides itself on being more Western and European than its neighbours to the north. Linguistic and epistemic liberation are therefore entwined with scatological and sexual imagery throughout the Mapurbe collection. The mutations, corporeality and images of procreation in Aniñir's work that correspond to Mapuche cosmovision are used to contest the Christian religion, but are also connected to a belief system based on ecocentrism. Although untied to his ethnicity, the maintenance of ecological balance is increasingly put forward as the last word in Parra's work. Before delving into the significance of their mutual ecological message, I wish to call attention to the strategy of desacralization that both poets use to lay bare the duplicity behind the institutions that uphold the values of capitalism.

Building on the work of scholars such as Iván Carrasco (1999) and Federico Schopf (1963) who recognize the deconstructive character of antipoetry as working towards a correcting of society, a recent article by Pilar Valenzuela Rettig (2014) combines the growing field of non-human studies in anthropology with a semiotic approach. Unlike other readings of Parra's work that see a break between his antipoetry and the ecopoetry of his latter years, Valenzuela Rettig roots Parra's concern with the human/non-human relationship in the earlier work of Poemas y antipoemas (1954). This is explored through the presence of everyday objects, the personification and value of nature, the desacralization of the religious subject/object, and the subsequent critique of the modern world and individual as constituents of an antipoetic text. Such desacralization is explored by Aniñir's work to the same end, ultimately leading him to re-sacralize elements of life that promote physical continuity and coexistence. As Valenzuela Rettig illustrates in her analysis of Parra's "Desorden en el cielo" (1954), central to such a quest is the tackling of institutionalized greed in the Catholic Church; exposing its role in knowledge production is key to reconnecting individual spirituality and the natural world.

The Church as a cornerstone of colonization is thus presented as sinister and depraved. Parra and Aniñir play with the language of the Lord's Prayer, subverting the imagery and realigning the Christian God with one steeped in the interests of politics. From Parra's image of a kind of helpless God "lleno de toda clase de 
problemas" ([1969] 1983, 71), Aniñir's goes a step further in his blasphemy and equates God's name to something rotten: "putrificado sea tu nombre" $(2009$, 47). Aniñir's God does not venture further than the Central Business District of the city, and "sólo entiende inglés" $(2009,67)$. The deliberate juxtaposition of English and broken families ("en el nombre del padre soltero / del hijo huérfano / and the saint spirit", 47) illustrates how wealth connects the elite of Chile to the English language, and continues to be safeguarded by the USA and Europe. Mass corporations supported by "los que viven en los faldeos de la reina / y en las condes", the most privileged areas of Santiago, support "los fascistas en la tierra / — nuestra tierra-" (47). The poetic voices in Parra's "Padre nuestro" are grovellingly sympathetic, showing their solidarity with God: "nosotros lloramos contigo" ([1969] 1983, 125). The Devil laughs and mocks the deity while humans kowtow to an inept deity and reassure him that they understand his predicament: "sabemos que el Demonio no te deja tranquilo / DeSconstruyendo lo que tú construyes”.

In their deconstruction of the sacred prayer, Aniñir and Parra emulate the actions of the demon. Parra's inclusion of the "s" in the verb deconstruir points towards deconstruction in the Derridan sense, and draws parallels between his antipoetic mission and demonic disruption. The manifestation of the profane is one among many playful strategies used by Mapurbe artists and poets to reverse the forces of spiritual colonization, often perceived as a sustained attack on the Mapuche knowledge system (feyetun) since the Conquest (Collins 2014). In "Salmo 1997" (2009, 47) the subversion of a god who only protects the rich becomes the only option for those living on the periphery. The triumph of physical continuity plays out in other poems ("Mapurbe" [75-76]; "Poetry Pewman" [65-68]) when Aniñir's spirit metaphors (wekufe) are used to take revenge for imposed marginalization (Collins 2014, 3840). The unification of Poetry and sex is also utilized to avenge Mapurbe for their alienation from their ancestral homeland; through the physical act of procreation the Mapurbe are reunited with Wall Mapu $(2009,25)$. The celebration of carnal pleasures is not limited to the Mapurbe, however, but can also be seen as a victory over Catholic guilt and shame. The unification of the physical and metaphysical is achieved through orgasm.

Although some critics view Parra's celebration of the purely sensory as a lastditch carpe diem (Yamal 1984, 24), I would argue that it also corresponds to the quest for beauty "debajo de la mierda". Following Yamal's (1984) analysis of cannibalism in Parra's work, we can see that ingestion of Catholic dogma, much like that of the Body of Christ, leads to its ultimate digestion in the form of human waste. Such iconoclasm is not representative of nihilism; the world as "una gran cloaca" in "Los vicios del mundo moderno" (Parra [1969] 1983, 45) demonstrates that human physical functions undermine any attempt to establish propriety and order on the natural world. While for Aniñir, semen, ejaculation and bodily functions are proof against the extermination/invisibility of the indigenous in the city, physical objects here (a 
man's armpit, a woman's sex, a louse) testify to the existence of the physical world, and fly in the face of those (movie stars, modern industrialists) who deny it. The triumph of nature underpins Parra's conviction that "la verdad, como la belleza, no se crea ni se pierde" (46). Read in conjunction with the final stanza, truth like beauty is found in the everyday pleasures of copulation; Parra's later assertion that sex was the foundation of antipoetry supports this reading (in Benedetti 1969, 14). ${ }^{5}$

The predominance of physicality ("la poesía de la tierra firme") is emphasized in the last stanza of Parra's "Manifiesto" ([1969] 1983, 157):

Contra la poesía de las nubes

Nosotros oponemos

La poesía de la tierra firme

-Cabeza fría, corazón caliente

Somos tierrafirmistas decididos-

Contra la poesía de café

La poesía de la naturaleza

Contra la poesía de salón

La poesía de la plaza pública

La poesía de protesta social.

Composed in the tradition of Horace's guidelines of what poetry should be, dating back to approximately 14 BC, Parra's 'Ars Poetica' reiterates the necessity for poetry in society but moves it away from simulations and abstractions of nature to places where it can be accessed through instinct rather than intellect: "El pensamiento no nace en la boca / Nace en el corazón del corazón" (154). Rather than adhering to celestial planes, the poet connects his power to the physical wellbeing of things on Earth: "El poeta está ahí / Para que el árbol no crezca torcido" (155).

Aniñir's "Arte peótika" explores his own social exclusion from the literary world. "Al peo" is Chilean slang for "work done half-assed" or badly done, but it also plays on the word peo (pedo, "fart") to mock both his own effort and the notion of poetry as an elitist pastime. Speaking from the position of a self-taught manual labourer, he represents potential poets who will never produce profitable art:

Los miserables orígenes de la poesía son desconocidos

En escritorios, editoriales y bibliotecas

Los orígenes paupérrimos de este Arte

Desarte

o desastre

Son inmundos $(2009,72)$

Those "inmundos" (taken from one of Parra's ecopoems) can be understood as both the underdogs of a capitalist system, and simultaneously as the urban, pos-tierra

5 Donald L. Shaw $(2008,39)$ makes this connection when he cites Parra's truly sacred moment as that of the orgasm.

JAPS-REVESA 1 (2018): 1-18. 
Mapuche (Aniñir 2009, 34). The poem is a state entered from the spirit world of Wenu Mapu, "estado subliminal de conciencia / pos estado de descomposición/engaño corporal en su máxima esencia / escritural acción torturando el silencio / asesinato innato del espacio vacío / al abismo del poema" (2009, 73). Ultimately, Aniñir concludes that the continuation of poetry (Mapu, the spiritual connection with Earth) is evident in the bodily functions of the poet and that the poet is indeed an extension of Mapu (the physical world), albeit a "desert" as opposed to the wetlands of the south: "y a pesar de los desiertos / las flores silvestres seguirán creciendo en tu tierra" $(2009,72)$. As is demonstrated in "Manifiesto", the body is sufficient proof of beauty and truth. The poet becomes the medium through which the ancestral message (el poema/poewma) comes through. Following on from Parra, Aniñir rejects Vicente Huidobro's creationist notion of the poet as "un pequeño Dios" because, as he writes, "entiendo la poesía no como el ave sino como el vuelo / (a las aves no me las toquen más en su virtud aérea, / joh! poetas)" (2009, 74). Vuelo here can also be seen as close to a volá, the high one gets from synthetic drugs. Poetry is the drug that enters the vein "alterando las pulsaciones", poisoning the skin that covers the soul $(2009,73)$. The poetry that emerges is menacing and rancid, "escurriendo hemorragias amarillentas y pus del pecho / embelleciendo el temple del reo sangrando ira" $(2009,74)$, but is a sign that the body is still connected to the physical world.

Reconnecting the physical with the spiritual outside the bounds of literary convention and social order counters understandings of the world that have been heavily influenced by the Enlightenment. Reference to concepts that recur in Chilean poetry can differ in meaning; silence, light, knowledge and freedom often trigger different codes when understood from indigenous perspectives. Moreover, with the development of indigenous canons in conjunction with calls for global trans-indigenous readings of indigenous texts, such alternative understandings are set to multiply (Allen 2012). This, in turn, enriches our own readings of regional literatures. The final section of this article looks at how Parra couples anti-consumerism with Mapuche values, and, from his own scientific perspective, calls upon the reader to see such a union as a viable solution to urgent environmental problems.

\section{"La belleza debajo de la mierda": A Shared Ecological Vision}

$\mathrm{M}$ uch of Mapuche cultural production revolves around a call for ecological cooperation, although critical attention has only recently considered the role of Мари (the Earth) among urban-based artists and writers. The spaces of dialogue that have opened up as a consequence of ecocriticism and environmental justice demonstrate that increased co-operation is conceivable, particularly with a growing interest in the interplay between science and poetry. The common objective between Parra and Aniñir discussed in this article is illustrative of such a tendency. For Parra, 
this desire for dialogue is more obvious in his ecopoetry, although we have seen that an ecological conscience is also present in his earlier collections. Aniñir alternates between a playful antipoetic tendency and a more direct engagement with other forms of Mapuche poetics that correlate with a didactic function associated with the Mapuche concept of kimún, roughly translated as "wisdom" (Collins 2014; Chihuilaf 1988, 1999, and 2002; Lienlaf 1990). Such variations result in a changing role for the poet as well as in new poetic forms.

In some poems by Aniñir we see a shift from the playfulness to a more serious type of oration where language is not used in the same way, and is devoid of neologisms and irony. In such cases the poem takes on an overtly didactic or political function. This can be seen in the opening poem of Mapurbe, "Yeyipun" (Aniñir 2009, 21-22), which is written entirely in Mapudungun and is a homage to those fighting in the spirit of ñuke Mapu (Mother Earth) as well as being a ceremonial poem that invokes his ancestors in their territorial struggle. Rather than acting as antipoet, Aniñir becomes social activist where his message is stripped down to the bare message. This becomes more common in the poems of Haykuche (2008), where the concept of the haiku combines with "una Mirada cósmica heredada de nuestros ancestros y que se erige como una sabiduría del buen vivir o una enciclopedia para la comprensión del mundo, útil desde el territorio en que se requiera dar sentido o este impresionante caudal de potentes enseñanzas" (Víctor Huenufil Vivanco in Aniñir 2008, 4).

An example of this dual function is Aniñir's treatment of newen/kimún, which roughly translate as "energy" and "wisdom", dualistic but complementary parts of a whole as understood from an indigenous perspective (Bacigalupo 1998; Grebe, Pacheco, and Segura 1972). Such virtues are alluded to in "Hacerla corta" when he urges young Mapuche people to explore their Mapu territory and be at once the energy associated with youth (newen) and age (kimún): "sé joven al fornicar y Viejo al enseñar" (2009, 24). When Aniñir calls his beliefs newendy (a combination of newen, "force", and wendy, Chilean slang for something done well or cheerfully), he rejects the idea that rigid morals define his understandings of Mapuche spirituality, as they themselves repress individual freedoms. In Haykuche, where the poem is less narrative in nature and distills concepts to fewer syllables, Aniñir outlines the concepts more clearly and abandons such antipoetic devices:

El kultrún guía nuestro espíritu

Él va allá donde habita quien es UNO

Pero a la vez son cuatro:

"es hombre y es mujer

es Viejo y es joven".

Ese UNO no se ha dado nombre.

Porque ÉL ES, es UNO, y es TODO. $(2008,82)$ 
Likewise, the existential distinction between the way the Earth is viewed in the Western/European tradition differs from traditional Mapuche perspectives. This is explained to the reader in Haykuche when az mapu (the laws of the Earth) unite the spirit and body with the natural elements:

Nuestras leyes tienen que ver con

La luna, la lluvia, y los Astros.

Nuestra religión tiene que ver con

La cordillera, el sol y los ríos.

Nuestro pensamiento no agoniza en

Esta existencia. $(2008,80)$

Here the desire to communicate "our laws" to a non-indigenous reader is reminiscent of Elicura Chihuailaf's (1999) desire to send a message to the Chilean people. The transmission of indigenous wisdom is viewed as essential in any attempt to reconcile differences between the reciprocal indigenous relationship with nature and the inherently capitalist system of the winka (Chilean). Passing on ancestral knowledge, and communicating with the other for the greater good of Mother Earth is therefore viewed as acting out of kimún. ${ }^{6}$

The increasing pedagogical tendency of Parra's ecopoems, which Niall Binns links to "la sentenciosidad incisiva" (2006, LXIX) first found in the antipoet's Artefactos (1972), also stems from a desire to communicate with the reader in the most direct manner possible. Like many indigenous groups who perceive that the purpose of their existence is to ensure a reciprocal relationship with the Earth, Parra was taken by a sense of urgency which translated into a didactic tone in his later work. He begins to see the poet as a "fabricante de pancartas. Ponte tú, un tipo de pancarta: 'El error consistió en creer que la tierra era nuestra, cuando la verdad de las cosas es que nosotros somos de la tierra"' (in Morales 1992, 119). Parra recognized a transition in his life's objective, moving in his work from a preoccupation with language and poetry to becoming more useful for humanity. When accepting his honorary doctorate at the University of Concepción in 1996, his sole objective was an ecological one, his final word on all matters:

\section{EN RESUMEN}

$$
\text { En síntesis }
$$

En pocas palabras:

Muchos los problemas

\footnotetext{
6 The integration of kimún and newen in Mapuche resistance is illustrated in Recado confidencial a los chilenos when Chihuailaf $(1999,128)$ writes: "La lucha por la defensa de nuestra tierra tiene que ver con la Ternura, dice nuestra gente. Porque ella — para todos los Pueblos indígenas del continente y del mundo- es la Madre Tierra."
} 
Una la solución:

Economía Mapuche de Subsistencia:

Hay que cambiarlo todo de

O nó dicen Uds. . $(2009,496)$

Parra later emphasizes the importance of this statement as "lo más importante que yo he visto, que yo he encontrado en mi modesto desarrollo" (quoted in Quezada 2007, 34), citing what he sees as inherent anti-consumerism among the Mapuche. Although this could be taken as an essentialist view of Mapuche culture, he appeals to the reader to rethink the position of humans in relation to other living beings. This perspective, evident in one of Parra's brief ecopoemas, puts forward the image of the Earth as an organism that will eventually shake off the destruction caused by parasitic humans:

Buenas Noticias:

la tierra se recupera en un millón

de años

Somos nosotros los que desaparecemos $(1989,163)$

While the poem is characteristically lacking in metaphor, and does not attribute emotion or human characteristics to the Earth, the latter is sentient in that it has a function beyond merely providing for its inhabitants. As Parra slips into the role of science teacher in his later poetry, he departs from the object of ridicule in the classroom to focus on a definitive message.

In "Estimados alumnos" $(1983,158)$, the poet-teacher's final words are in the form of concrete orders to protect the environment, making a correlation between poetry and the future of Chilean wildlife:

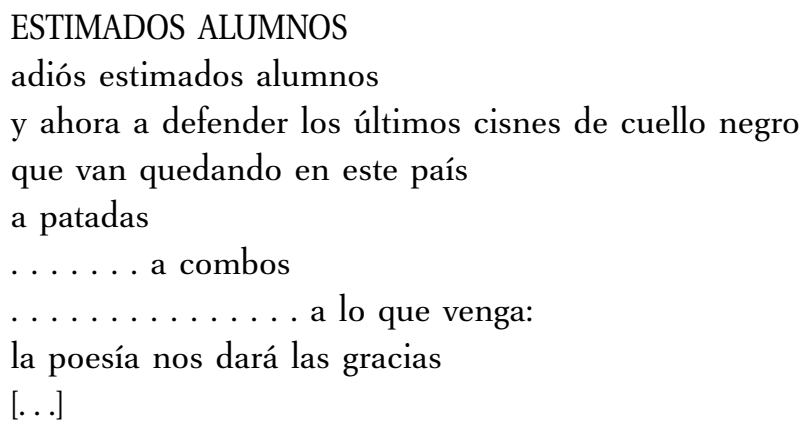

This is a departure from Parra's earlier work, which characteristically avoided expressing any convictions or ultimatums. However, as Mauricio Ostria González 
(2010) argues, all that changes here is the shift in the function of the poet, rather than the antipoetic strategies that are by now so familiar to Parra's readers. The voice becomes a type of prophet and defender of the Earth, a "poeta de la tribu, que se siente parte de una comunidad en peligro" (186). The poem "Estimados alumnos" became more potent to Chileans years after it was written, as it foretold the ecological disaster that occurred in 2004 when untreated waste from a pulp mill led to the mass death of swans in the Río Cruces Sanctuary, a protected wetland near Valdivia.

\section{Conclusion}

Some lament Parra's transition from antipoetry to ecopoetry, as though his ex$\mathcal{S}$ plicitness somehow made him a poor imitation of himself, or that his poetry decreased in literary value along with a fading sense of humour (Valero 1991). Perhaps, the mistrust of place that Höefler (in Quezada et al. 2015) saw as key to Parra's irony was reconciled in his old age, upon realizing that his purpose was aligned to the previous occupiers of those abandoned houses. The function of the poet was amplified, as it is in much of Mapuche poetry where the objective is to dialogue and teach the other about an alternative knowledge system that does not view nature as an economic resource.

However, this article has shown that such ecological preoccupations were always present in Parra's work. Jill S. Kuhnheim $(2014,210)$ argues that Parra demystified the poet in order to remystify it and that poetic practice was renewed through its own repudiation and destruction. I have explored this process thematically in both Parra and Aniñir through the desacralization of language, social systems and literature, concluding that physical continuity, that is to say, the living organisms that thrive after being stripped of all order imposed upon them, is the impulse behind their poetic production.

\section{Works Cited}

Allen, Chadwick. 2012. Trans-indigenous: Methodologies for Global Native Literary Studies. Minneapolis: Univ. of Minnesota Press.

Aniñir, David. 2008. Haykuche. Santiago de Chile: Independent.

—. 2009. Mapurbe: venganza a raíz. Santiago de Chile: Pehuén.

—. 201la. "Autoretraxto". Mapurbe (blog), 8 September.

URL: http://mapurbe69.blogspot.com/2011/09/autoretraxto.html.

Aniñir, David. 2011b. Interview with Sandra Collins. Personal interview. Santiago de Chile, 11 May. 
Aravena, Andrea. 2002. "Los mapuches-warriache[:] procesos migratorios e identidad mapuche urbana en el siglo XX." In Colonización, resistencia y mestizaje en las Américas (siglos XVI-XX), edited by Guillaume Boccara, 359-85. Lima: IFEA; Quito: Ediciones Abya-Yala.

Bacigalupo, Ana Mariella. 1998. "The Exorcising Sounds of Warfare: The Performance of Shamanic Healing and the Struggle to Remain Mapuche." Anthropology of Consciousness 9:1-16. DOI: https://doi.org/10.1525/ac.1998.9.2-3.1.

Barrera García, Mabel. 2008. "El 'pewma' en la poesia mapuche." Papeles de trabajo - Centro de Estudios Interdisciplinarios en Etnolingüística y Antropología Socio-Cultural 16:1-14.

Benedetti, Mario. 1969. "Nicanor Parra o el artefacto con laureles." Marcha, 17 October, 13-15.

Binns, Niall. 2006. Introduction to Obras completas \& algo † (1935-1972), by Nicanor Parra, XXIX-LXXVI. Barcelona: Círculo de Lectores.

Cárcamo-Huechante, Luis E. 2010. "Wixage anai!: Mapuche Voices on the Air." The New Centennial Review 10 (1): 155-68. DOI: https://doi.org/10.1353/ncr.2010.0021.

Carrasco, Iván. 1999. Para leer a Nicanor Parra. Santiago de Chile: Cuarto Propio.

Chihuilaf, Elicura. 1988. En el país de la memoria (Maputukulpakey). Temuco: Quechurrewe.

- 1999. Recado confidencial a los chilenos. Santiago de Chile: LOM.

—. 2002. De sueños azules y contrasueños. Santiago de Chile: Huerga y Fierro.

Collins, Sandra. 2014. "Mapurbe: Spiritual Decolonization and the Word in the Chilean Mierdópolis.” Decolonization: Indigeneity, Education \& Society 3 (1): 23-47.

"Conversa con el David-Desde los territorios asfaltados de Cerro Navia." 2004. MapUrbe'zine 3 (8). Especial Nekro-lógicas II: 2da parte. URL: https://hemi.nyu.edu/cuaderno/wefkvletuyin/david.htm.

Crow, Joanna. 2008. "Mapuche Poetry in Post-Dictatorship Chile: Confronting the Dilemmas of Neoliberal Multiculturalism." Journal of Latin American Cultural Studies 17:221-40. DOI: https://doi.org/10.1080/13569320802228062.

-. 2015. "Literary Acts of Decolonisation: Contemporary Mapuche Poetry in Santiago de Chile." Liminalities: A Journal of Performance Studies 11 (3): 1-28.

Garside, Grace Ellen. 2016. "Multiple Masculinities: An Exploration of Urban Mapuche Youth Identities in Chile." PhD diss., Durham University.

URL: http://etheses.dur.ac.uk/11971/.

Geeregat, Orietta and Pamela Gutiérrez. 1992. "Se ha despertado el ave de mi corazón: Texto-Kultrung." Actas de Lengua y Literatura Mapuche 5:137-44.

Gómez-Barris, Macarena. 2012. "Mapuche Hunger Acts: Epistemology of the Decolonial." TRANSMODERNITY: Journal of Peripheral Cultural Production of the Luso-Hispanic World 1 (3): 120-32. 
Grebe, María Ester, Sergio Pacheco, and José Segura. 1972. "Cosmovisión mapuche." Cuadernos de la realidad nacional 14:46-73.

Haughney, Diane. 2012. "Defending Territory, Demanding Participation: Mapuche Struggles in Chile." Latin American Perspectives 39 (4): 201-17. DOI: https://doi.org/10.1177/0094582X12441515.

Kropff, Laura. 2004. "Mapurbe: Jóvenes mapuche urbanos." Revista de Temas Sociales 14:1-12.

-. 2011. "Los jóvenes mapuche en Argentina: Entre el circuito punk y las recuperaciones de tierras." Alteridades 21 (42): 77-89.

Kuhnheim, Jill S. 2014. Beyond the Page: Poetry and Performance in Spanish America. Tuscon: Univ. of Arizona Press.

Lienlaf, Leonel. 1990. Se ha despertado el ave de mi corazón. Santiago de Chile: Universitaria.

Merino, Eugenia D. 1999. "El discurso 'wewpin' en la etnoliteratura." Onomazein 4:321-33.

Mignolo, Walter. 2000. Local Histories/Global Designs: Coloniality, Subaltern Knowledges, and Border Thinking. Princeton: Princeton Univ. Press.

Mora Curriao, Maribel. 2007. "Identidad mapuche desde el umbral (o la búsqueda de la mismidad étnica en el Chile de los noventa)." In Intelectuales indígenas piensan América Latina, edited by Claudia Zapata, 29-44. Quito: Abya-Yala.

Morales, Leonidas. 1992. Conversaciones con Nicanor Parra. Santiago de Chile: Editorial Universitaria.

"Nicanor Parra (1914-2018): Poetas despiden al antipoeta." 2018. The Clinic, 23 January. URL: http://www.theclinic.cl/2018/01/23/poetas-despiden-al-antipoeta/.

Osorio Santibáñez, Líber. 2009. "Inche Mapurbe Ngen. De chorizo a weichafe: nuevos elementos culturales en la identidad mapuche de Santiago, 1997-2009." $\mathrm{PhD}$ diss., Universidad de Chile.

Ostria González, Mauricio. 2010. "Notas sobre ecocrítica y poesía chilena." Atenea 502:181-91.

Parra, Nicanor. 1954. Poemas y antipoemas. Santiago de Chile: Nascimento.

—. (1969) 1983. Obra gruesa. Santiago de Chile: Andrés Bello.

—. 1983. Poesía política. Santiago de Chile: Bruguera.

—. 1989. Chistes para desorientar a la poesía. Madrid: Visor.

—. 2009. After-Dinner Declarations. Bilingual Edition. Translated by Dave Oliphant. Austin: Host Publications.

Preston, Jon. 2017. Remembering a Different Future: Dissident Memories and Identities in Contemporary Chilean Culture. PhD diss., Victoria University of Wellington. URL: https://tinyurl.com/yahd37y8.

Quezada, Jaime. 2007. Nicanor Parra de cuerpo entero: vida y obra del antipoeta. Santiago de Chile: Andrés Bello. 
Quezada, Jaime, Floridor Pérez, Federico Schopf, Walter Höfler [sic], Clemente Riedemann, David Wallace, and Horst Nitschack. 2015. "Coloquio "Nicanor Parra: diálogos sobre la (in)actualidad de la antipoesía.'” Revista Chilena de Literatura 91:147-79.

Samaniego Mesías, Augusto and Carlos Ruiz Rodríguez. 2007. Mentalidades y políticas Wingka: Pueblo mapuche, entre golpe y golpe (de Ibáñez a Pinochet). Madrid: CSIC.

Santillán, Laura "Xiwe". 2014. "Entrevista al Poeta Aniñir: Mi poesía se defiende sola." La Izquierda, 12 October.

URL: http://www.laizquierdadiario.com.mx/Mi-poesia-se-defiende-sola.

Schopf, Federico. 1963. "Estructura del antipoema." Atenea 399:140-53.

Shaw, Donald L. 2008. Spanish American Poetry After 1950: Beyond the Vanguard. London: Tamesis.

Valenzuela Rettig, Pilar. 2014. "Lo humano y no-humano en Poemas y antipoemas de Nicanor Parra." Estudios filológicos 54:177-92. DOI: https://doi.org/10.4067/S0071-17132014000200010.

Valero, Roberto. 1991. "Función del humor en la obra de Nicanor Parra." Hispania 74 (1): 210-13. DOI: https://doi.org/10.2307/344587.

Yamal, Ricardo. 1984. "Antipoesía o antropofagia: 'Los vicios del mundo moderno' de Nicanor Parra." INTI: Revista de Literatura Hispánica 20:17-27.

—. 1986. "Entrevista con Nicanor Parra." Discurso Literario 3 (2): 275-88. 